\title{
A Relação intergeracional no livro Clara na Música Popular
}

\author{
Kátia Milene Lima da Conceição (UNESP, São Paulo, SP) \\ katiavibes@gmail.com
}

Resenha do livro BOLLOS, Liliana Harb. Clara na música popular. São Paulo: Som, 2011; 80p. R\$20.

Esta publicação de Liliana Bollos é dedicada ao público juvenil. A protagonista é uma jovem envolta com o vestibular e questões peculiares dessa fase da vida, interessando-se pela música através da descoberta apaixonante de contextos musicais que a seduzem e a estimulam a aprofundar seus conhecimentos, inclusive, através de meios e relações afetivas.

O livro Clara na música popular tem oitenta páginas distribuidas em vinte capitulos sucintos, onde aspectos da história da música popular são discorridos informalmente, mas inspirador à pedagogia musical nesse tema emergente para o público adolescente. A proposta é apresentar um texto envolvente e adequado a esta faixa etária, já que os adolescentes possuem motivações pertinentes a essa fase da vida. A linguagem é de fácil assimilação, o conteúdo estimula o leitor a se aprofundar no material exposto com algumas sugestões de bancos de dados de universidades e sites correlacionados no final do livro. Atualizada com a mídia emergente e consciente do valor da internet, a educadora traz atraentes indicações nesse meio, pois não se pode excluir as novas tecnologias e demais recursos considerados agentes transformadores contemporâneos. Estas dicas sugerem analogia com a extensa conectividade, não só com a internet, mas com outros aspectos como as questões afetivas e relacionais da educação musical.

A publicação tem uma divisão interessante de temas. Começa com o sonho da Clara passando pelas férias no interior de São Paulo, a relação com a família, vizinhos, sua melhor amiga, as paixões, o vestibular até a entrada na faculdade. Os assuntos são encadeados de forma didática, mas informal, e aspectos da música brasileira (choro, samba, marcha, bossa nova) e do jazz (ragtime, new orleans, dixieland, swing, bebop) são traçados e relacionados historicamente; longe de ser tedioso para um público adolescente. 
No primeiro contato com o livro, a multiplicidade de informações apresenta um conteúdo didático e simbólico, desencadeando um atraente processo de escolhas, dependendo do interesse e do momento do leitor. Destaco no livro o aspecto intergeracional simbolizado nas relações de Clara. Mesmo que não tenha sido a intenção consciente da escritora, já que o significado estabelecido primariamente pode ser transformado a cada leitura, a intergeracionalidade está presente no texto de forma envolvente. Se a ideia inicial não foi relatar estas relações ou abordar este aspecto diretamente, com certeza proporcionou a reflexão e 0 desejo de cultivar e reforçar estas relações.

Alguns capítulos merecem destaque por mostrar justamente esta relação intergeracional. Em Minha família e o Samba, Clara demonstra todo o aprendizado que pode desfrutar dessa convivência familiar, configurado na educação informal gerada pelos vínculos entre pais, filhos, irmãos e amigos, através da reciprocidade relacional. 0 capítulo As férias de Clara ilustra como uma convivência prazerosa entre vizinhos, tios e primos pode trazer saberes para a vida, que é possível aprender muito em uma conversa e no convívio com a diversidade. As músicas preferidas de meus avós relata o aprendizado entre gerações, ilustrada por Clara e seus parentes, enfocando o poder da linguagem emotiva, da transmissão oral repleta de afabilidade, estabelecida também pela relação entre gerações diferentes, que se mostra benéfica e mobilizadora de ação mútua. Quando as pessoas que Clara se relaciona discorrem sobre suas lembranças musicais, observa-se como a música foi marcando a trilha sonora da vida delas, como o fator cultural e arrebatador da escuta, da memória emocional sonora se presentifica e se mostra impactante no corpo e no aspecto afetivo cada vez que é rememorada. 0 capítulo Conversa com Alberto sobre as fases do Jazz, mostra o crescente interesse pelo Jazz estimulado pela paixão platônica, típica da adolescência, por Alberto, marcada também pelo conhecimento obtido através de curiosas fontes de informações e emoções.

0 último capítulo, com o título sugestivo 0 fim será o começo narra as perspectivas que esta experiência trouxe para a Clara estimulando-a a buscar novos horizontes de conhecimentos. As "entrelinhas" mostraram 0 aspecto projetivo da música, onde a adolescente pode ter consciência de suas descobertas que refletem 0 momento vivido, seu processo de aprendizado e sua relação no contexto.

É notório observar como existem constructos que estão presentes em várias áreas psicopedagógicas e nas artes, ratificando como a música pode ser projetiva de um momento presente com questões vivenciadas, nesse caso por Clara, mas que também podem ser estendidas e identificadas com outros, inclusive de idades diferentes, o que ocorre, por exemplo, com os avós de Clara. Ou seja, em qualquer fase pode existir uma representatividade musical simbólica e afetiva. Certas situações de descobertas podem ser motivadas por contingências diversas em várias fases e momentos da vida. Assim como a personagem desenvolve a consciência do que está vivendo e do processo em que está inserida, através de sua relação com questões musicais nesse mesmo núcleo afetivo, outras pessoas também se deparam com situação similar, ilustrando o poder mobilizador da música.

A escolha por enfatizar a questão intergeracional se sobrepõe a exposição do conteúdo musical que obviamente já promove no leitor a curiosidade para buscar maiores informações sobre o que foi narrado. A convivência entre as gerações descrita de forma leve e cativante em um ambiente harmonioso resulta no aprendizado não só para a Clara, mas para os demais envolvidos. A troca de experiências e saberes, o intercâmbio entre diferentes gerações exposto neste livro demonstra os ganhos da relação intergeracional para os envolvidos no processo, fortalecendo os laços afetivos. Algumas experiências já demonstraram que a convivência intergeracional pode ser uma das responsáveis pela mudança da imagem da velhice em uma concepção positiva, quebrando com mitos e tabus inerentes ao processo natural e sociocultural do envelhecimento no Brasil, rompendo inclusive com o isolamento dos idosos na sociedade, principalmente com relação às gerações mais novas.

A obra mostra, por exemplo, como Clara sente-se motivada a interagir com os mais velhos, demonstrando que a relação intergeracional é uma ferramenta que realmente promove a aproximação, renovação, respeito, trocas de experiências, habilidades e saberes. Um recurso capaz de modificar até uma realidade preconceituosa anteriormente predominante, um benefício mútuo.

Continuando com o conteúdo simbólico das entrelinhas do livro, em certos trechos há reprodução de representações socioculturais de alguns estilos abordados, absorvidos pelos brasileiros e repetidos em diversos meios. A escritora situa-os historicamente e tenta ser imparcial, mas não deixa de colocar a representatividade dos estilos ainda predominante na contemporaneidade. Porém há certas representações que precisam de questionamentos e visão crítica para que não se busque reproduzir sem reflexão sobre o contexto. No terceiro capítulo a autora coloca que é preciso "estudar música clássica para melhorar a técnica no instrumento e deixar os dedos bem leves" (p.18), reforçando uma concepção que já é questionável, pois logicamente que é necessário um domínio técnico do instrumento, mas a música clássica não é o único caminho para chegar a este patamar. No entanto, esta concepção, não tira a significância do material, pois ainda existe uma lacuna que o conhecimento acadêmico tenta preencher satisfatoriamente com materiais que consigam realmente atingir o público juvenil, que tem motivações e aspirações particulares, nem sempre fáceis de serem atingidas por alguns professores da área, que ainda utilizam como referência, métodos de 
musicalização infantil com adolescentes. Este exemplo serve para ilustrar a necessidade de reexaminar o que está consagrado como certo, refletindo sobre conhecimentos, representações, posturas, procedimentos e teorias. 0 saber deve ser reavaliado e reconstruído de acordo com a demanda histórica e educativa. Não existem métodos universais infalíveis, mas sugestões fundamentadas na ciência, em dados históricos, em livros adequados ao público que se está trabalhando, norteando, assim, a ação do educador musical.

A escritora Liliana Bollos possui diversas publicações em circuitos interdisciplinares de atuação. Circula entre a área popular e erudita com muita intimidade devido a sua ampla vivência e concepção diversificada nestes campos. É doutora em Comunicação e Semiótica, mestre e bacharel em performance em piano jazz, bacharel e licenciada em letras, formada em piano clássico, dentre outras qualidades marcantes que a fazem discorrer com muita propriedade sobre a diversidade e a multiplicidade do contexto musical em que atua.

Esta obra é recomendada para profissionais da música que trabalham ou pretendem trabalhar com adolescentes, assim como demais interessados no tema, incluindo o público para qual foi direcionado o texto: os jovens. É interessante por apresentar aspectos desta área, que de certa forma, ainda está em construção ou reconstrução abrangendo a história da música e outras questões pertinentes ao contexto juvenil.

Kátia Milene Lima da Conceição é psicóloga e musicista. Formada em piano e vibrafone. Mestre em Música pelo Instituto de Artes da UNESP. Exerce trabalhos camerísticos e como solista na área erudita e popular, além de ministrar aulas de instrumento e teoria musical. 